\title{
Pengaruh Suhu Permukaan Laut (SPL) terhadap Curah Hujan di Perairan Bali
} menggunakan Data Citra Satelit

\author{
Ni Kadek Martini ${ }^{\mathrm{a}}$, I Wayan Nuarsa ${ }^{\mathrm{a} *}$, I Wayan Gede Astawa Karang ${ }^{\mathrm{a}}$ \\ ${ }^{a}$ Program Studi Ilmu Kelautan, Fakultas Kelautan dan Perikanan, Universitas Udayana, Bali, Indonesia \\ *Corresponding author, email: nuarsa@gmail.com
}

\section{ARTICLE INFO}

\section{ABSTRACT}

\section{Article history:}

Received: June $8^{\text {th }} 2020$

Received in revised form: August $15^{\text {th }} 2020$

Accepted: August $25^{\text {th }} 2020$

Available online: August $31^{\text {th }} 2021$
Keywords:

Bali Water

MODIS

Rainfall

SST

TRMM

\begin{abstract}
Rainfall is a weather element. Sea surface temperatures (SST) affects precipitation. SST and rainfall have a high variability which can be measured by satellite. At a regional scale, a research of the effect of SST on rainfall analyzed island rainfall, which means that there is still little research on rainfall in the waters. This study purposed to find out the variability and correlation between SST and rainfall in the Bali waters. It used satellite MODIS and TRMM for 10 years, started from 2010 to 2019. The data used was SST MODIS and rainfall TRMM level 3 with the geographic coordinates boundaries area $114.4281^{\circ}$ East - $115.7145^{\circ}$ East, and $7.8168^{\circ}$ South $8.9868^{\circ}$ South. The method of this study was correlation analyzed with time lag between of SST and rainfall. The variability of SST in the Bali waters were ranged from $25,2{ }^{\circ} \mathrm{C}$ to $31,6^{\circ} \mathrm{C}$. Furthermore, the variability of rainfall was ranged from $0 \mathrm{~mm}$ to $556,92 \mathrm{~mm}$. The changes patterns of SST and precipitation in Bali water were related to the season in each month. The data showed that the SST was warmer in the rainy season compared to the SST in the dry season. Besides, the rainfall increases when entering the rainy season, and the decreases when entering the dry season. The correlation between SST and rainfall in this waters area ranged from weak to strong. Correlation formed in the rainy season is negative with a correlation coefficient between -0.34 to -0.74 . However, in the dry season there was a positive correlation with a correlation coefficient ranging from 0.77 to 0.92 .
\end{abstract}

2021 JMRT. All rights reserved.

\section{Pendahuluan}

Cuaca adalah variasi atmosfer jangka pendek sedangkan iklim didefinisikan sebagai rata-rata cuaca di suatu daerah (Miftahuddin, 2016). Menurut Kartasapoetra (2004) fenomena alam yang digerakkan oleh gabungan dari beberapa unsur cuaca seperti hujan adalah iklim. Hujan adalah bentuk dari presipitasi uap air yang bersumber dari alam (Triatmojo, 1998). Sementara itu, jumlah air hujan dalam satuan waktu tertentu disebut dengan curah hujan (Susilowati dan Sadad, 2015). Curah hujan mendapat pengaruh dari sirkulasi udara, pembentukan awan, serta kondisi lokal wilayah seperti suhu permukaan laut (SPL) (Hermawan, 2010).

SPL memiliki peranan yang cukup signifikan dalam proses terjadinya hujan (Lestari et al., 2017). SPL membantu laut menyuplai uap air yang berpengaruh pada tinggi rendahnya curah hujan (Wulandari dan Apriansyah, 2018). Menurut Wijaya (2015), fenomena akibat adanya hubungan antara SPL dengan atmosfer berpengaruh terhadap kerentanan kawasan pesisir dan aktifitas nelayan. Penelitian pengaruh SPL terhadap curah hujan dilakukan oleh Yadnya et al. (2015) dengan memperoleh hasil bahwa SPL Tenggara dan Barat Daya Pulau Bali memiliki nilai korelasi cukup kuat dengan curah hujan dalam kurun waktu tiap 10 hari di kabupaten/kota di Bali. Penelitian serupa juga dilakukan oleh Lestari et al. (2017) dengan hasil korelasi cukup kuat antara curah hujan dengan SPL 1 bulan sebelumnya di Kendari. Perubahan SPL dan curah hujan dapat dilihat dari variabilitas yang memerlukan pemantauan tepat agar dapat dilakukan langkah adaptasi terhadap dampak yang mungkin timbul (Sukreno, 2010). Variabilitas tinggi yang dimiliki oleh curah hujan dan SPL membutuhkan data observasi yang panjang dan sebaran secara spasial yang lebih baik (Prasetia dan AsSyakur, 2010).

Sharifi (2016) menyatakan bahwa saat ini pengamatan curah hujan secara insitu sangat kurang representatif karena jangkauan alat yang sangat sempit sehingga perlu instrumen pendukung yang dapat memberikan hasil gambaran lebih baik dari distribusi hujan dan sebagai penunjang akurasi data, salah satu alternatif yang dapat digunakan yaitu satelit. Pertiwi et al.(2015) melakukan kajian terkait SPL dan curah hujan menggunakan metode penginderaan jauh dengan satelit curah hujan Tropical Rainfall Measuring Mission (TRMM) dan hasil yang diperoleh yaitu curah hujan di Semarang dipengaruhi oleh SPL di utara Jawa Tengah dengan nilai regresi yang tinggi. Keakuratan data TRMM dibuktikan melalui penelitian Nugroho (2014) dengan membandingkan data curah hujan insitu pada 6 pos pengamatan di Sulawesi Utara dengan data curah hujan TRMM dan hasilnya, sebanyak 5 dari 6 pos memiliki kemiripan data dengan data TRMM. Wahdianty et al.(2016) juga melakukan verifikasi data curah hujan TRMM di Kalimantan Selatan yang memperoleh 
hasil bahwa data 69 pos dari 90 pos pengamatan yang dikaji memiliki nilai yang akurat dengan data curah hujan dari TRMM.

Pulau Bali merupakan kawasan Indonesia bagian tengah yang tercatat memiliki potensi cuaca yang ekstrim sehingga mengakibatkan kejadian bencana yang merugikan apabila tidak di antisipasi baik di darat maupun laut (Rindrasih dan Mujiasih, 2015). Penelitian terkait pengaruh SPL terhadap curah hujan di wilayah Bali sudah sering dilakukan dengan mengkaji curah hujan pada daerah daratan, karena daerah tersebut dinilai memiliki daerah pertanian yang luas dan memiliki produktivitas tinggi (Suharyanto et al., 2016). Selain darat, wilayah laut juga tidak kalah penting karena memiliki berbagai aktivitas yang dipengaruhi oleh cuaca (Wirjohamidjojo dan Sugarin, 2008). Mengingat pentingnya wilayah laut dan pentingnya ketersediaan data yang memadai terkait SPL dan curah hujan di suatu wilayah, maka dilakukan analisis variabilitas bulanan SPL dan curah hujan pada 10 tahun terakhir yaitu tahun 2010 sampai 2019 di perairan Bali agar memperoleh kondisi terbaru di wilayah kajian, serta mengetahui apakah SPL dari satelit Aqua/Terra memiliki korelasi terhadap curah hujan dari satelit TRMM di perairan Bali.

\section{Bahan dan Metode}

\subsection{Lokasi Penelitian}

Penelitian ini berlokasi di sepanjang pantai Kabupaten Gianyar. Periode data SPL dan curah hujan dalam penelitian ini selama 10 tahun yaitu 2010 sampai 2019 dengan mengambil lokasi di perairan Bali bagian Utara dan Selatan. Area penelitian ditunjukkan pada Gambar 1 dengan kisaran kordinat geografis $114,4281^{\circ}$ BT, 8,9868 ${ }^{\circ}$ LS, $115,7145^{\circ}$ BT, 7,8168 ${ }^{\circ}$ LS. Pembagian wilayah mengacu pada bentangan area pegunungan di bagian tengah dari Pulau Bali dari barat sampai timur lalu pada bagian selatan daerah pegunungan dibuat garis batas sehingga memisahkan bagian utara dan selatan (Adnyana dan As-syakur, 2012).

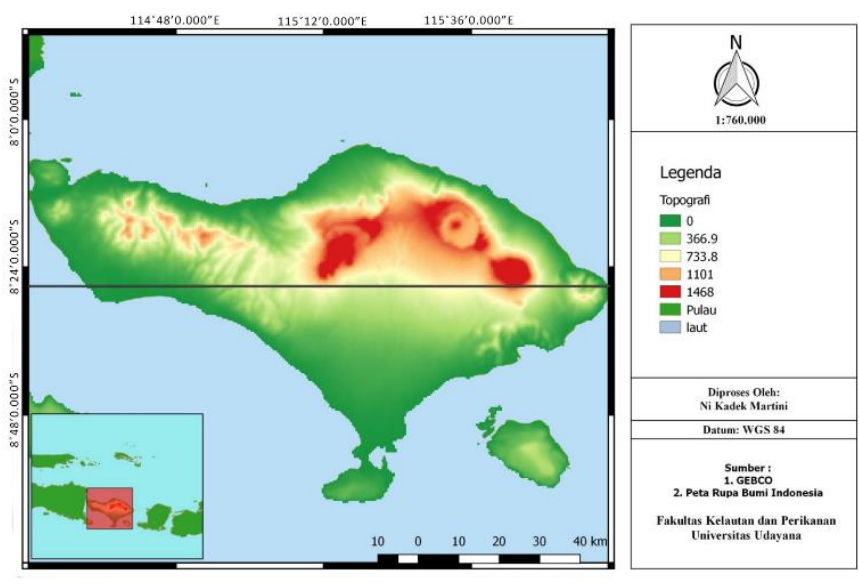

Gambar 1. Peta Lokasi Penelitian

\subsection{Metodelogi Penelitian}

Metode penelitian dibagi menjadi beberapa tahap yaitu, pengolahan citra Moderate Resolution Imaging Spectro Radiometer (MODIS), citra TRMM, data angin di perairan Bali, dan mencari korelasi SPL dengan curah hujan. Data SPL yang digunakan adalah data dari citra MODIS level 3 harian dari 2010 sampai 2019. Data yang digunakan pada penelitian ini dapat dilihat pada Tabel 1.
JMRT, Volume 4 No 2 Tahun 2021, Halaman: 1-7

Tabel 1. Parameter Penelitian

\begin{tabular}{|c|c|c|}
\hline Parameter & Resolusi Spasial & $\begin{array}{c}\text { Resolusi } \\
\text { Temporal }\end{array}$ \\
\hline $\begin{array}{c}\text { SPL MODIS } \\
\text { http://oceancolor.gsfc. } \\
\frac{\text { nasa.gov/Model }}{\text { (DEM) }}\end{array}$ & $4 \mathrm{~km}$ & 2 hari \\
\hline $\begin{array}{c}\text { Curah Hujan TRMM } \\
\text { http://giovanni.sci.gsfc }\end{array}$ & $27,75 \mathrm{~km}$ & $3 \mathrm{jam}$ \\
\hline $\begin{array}{c}\text { nasa.gov/giovanni. } \\
\text { Angin European } \\
\begin{array}{c}\text { Center for Medium- } \\
\text { Range Weather } \\
\text { Forecast } \text { (ECMWF) } \\
\text { http://www.ecmwf.int/ }\end{array}\end{array}$ & $13,87 \mathrm{~km}$ & $6 \mathrm{jam}$ \\
\hline
\end{tabular}

Analisis korelasi dilakukan untuk melihat hubungan antara SPL dengan curah hujan secara temporal selama 10 tahun dari tahun 2010 sampai 2019, serta hubungannya berdasarkan musim, yaitu musim barat dan musim timur. Musim barat meliputi bulan November hingga April dan musim timur dari bulan Mei hingga Oktober, mengacu pada Sudarto (2011).

\subsection{Pengolahan data SPL, data curah hujan, dan data angin}

Data SPL dari citra MODIS dirata-ratakan secara spasial untuk mendapatkan data rata-rata SPL bulanan. Untuk mempermudah analisis sesuai dengan tujuan penelitian, maka dilakukan pemotongan citra untuk membagi wilayah penelitian menjadi dua area, yaitu wilayah utara dan wilayah selatan. Setelah diperoleh data bulanan, kemudian variabilitas data selama 10 tahun ditampilkan pada grafik. Hal yang sama dilakukan pada citra TRMM untuk analisis curah hujan. Perbedaannya hanya terletak pada proses awal dimana data curah hujan tidak perlu dirataratakan terlebih dahulu karena sudah berupa data bulanan. Data angin bulanan selama 10 tahun di wilayah Indonesia diolah dengan software Ocean Data View. Informasi data yang diperlukan yaitu longitude, latitude, nilai $\mathrm{U}$ (kecepatan angin pada arah vektor $\mathrm{x}(\mathrm{m} / \mathrm{s})$ ), dan nilai $\mathrm{V}$ (kecepatan angin pada arah vektor y $(\mathrm{m} / \mathrm{s})$ ) untuk dilakukan perhitungan kecepatan dan arah. Selanjutnya data diolah dengan software QGIS sehingga diperoleh peta angin musim barat dan musim timur

\subsection{Analisis Hubungan SPL dan curah hujan}

Analisis korelasi secara temporal dilakukan setelah diperoleh hasil nilai rata-rata area SPL dan curah hujan pada area perairan Bali, perairan Bali Utara, dan perairan Bali Selatan. Dalam penelitian ini korelasi dilakukan dengan skenario time lag, dari lag 0 sampai lag 2. Lag 0 berarti curah hujan dipengaruhi oleh SPL pada bulan yang sama, kemudian lag 1 berarti curah hujan dipengaruhi oleh SPL 1 bulan sebelumnya, dan untuk lag 2 curah hujan dipengaruhi oleh SPL 2 bulan sebelumnya.

Koefisien korelasi SPL dengan curah hujan pada setiap lag dihitung dengan persamaan Kendall dan Struat (1947) sebagai berikut :

$$
r_{i}=\frac{\sum x y_{i}-\frac{\left(\Sigma x_{i}\right)\left(\Sigma y_{i}\right)}{n}}{\sqrt{\left(\sum x_{i}^{2}-\frac{\left(\Sigma x_{i}\right)^{2}}{n}\right)\left(\sum y_{i}^{2}-\frac{\left(\Sigma y_{i}\right)^{2}}{n}\right)}}
$$


Dimana r, $\mathrm{x}$, dan y masing-masing adalah koefisien korelasi, SPL, dan curah hujan, serta i menunjukkan data ke i (lag 0 sampai $\operatorname{lag} 2$ ). Perhitungan koefisien korelasi pada $\operatorname{lag} 0, \operatorname{lag} 1$, dan $\operatorname{lag} 2$, susunan nilai $\mathrm{x}$ yang digunakan sama. Pada lag 0 , susunan nilai y yang digunakan tidak memiliki selisih bulan dengan nilai x (SPL pada bulan Januari dengan curah hujan bulan Januari, dan seterusnya). Untuk perhitungan pada lag 1 susunan nilai y memiliki selisih 1 bulan (SPL januari dengan curah hujan Februari, SPL Februari dengan curah hujan Maret, dan seterusnya). Terakhir untuk lag 2, nilai y yang digunakan memiliki selisih 2 bulan (SPL Januari dengan curah hujan Maret, SPL Februari dengan curah hujan April, dan seterusnya). Selanjutnya, tingkat hubungan SPL dengan curah hujan diklasifikasikan dengan merujuk pada Tabel 2 sebagai berikut:

Tabel 2. Koefisien Korelasi

\begin{tabular}{|c|c|}
\hline Koefisien Korelasi & Tingkat Hubungan \\
\hline 0 & Tidak ada \\
\hline $0,01-0,25$ & Sangat lemah \\
\hline $0,26-0,5$ & Lemah \\
\hline $0,51-0,75$ & Kuat \\
\hline $0,76-0,99$ & Sangat kuat \\
\hline 1 & Sempurna \\
\hline
\end{tabular}

Sumber: Fadholi (2013)

Disamping perhitungan korelasi dengan seluruh data bulanan selama 10 tahun, analisis korelasi juga dilakukan dengan penggolongan musim barat dan musim timur. Kemudian dicari koefisien determinasi dengan menguadratkan nilai koefisien korelasi.

\section{Hasil dan Pembahasan}

\subsection{Variabilitas SPL dan Curah Hujan}

Variabilitas SPL dari tahun 2010 sampai 2019 di perairan Bali secara visual disajikan pada Gambar 2. Berdasarkan hasil yang diperoleh, nilai bulanan SPL selama 10 tahun di perairan Bali Utara berkisar $27,7^{\circ} \mathrm{C}$ sampai $31,2^{\circ} \mathrm{C}$ dengan rata-rata $29,5^{\circ} \mathrm{C}$, sedangkan SPL di perairan Bali Selatan berkisar $25,2^{\circ} \mathrm{C}$ sampai $31,6^{\circ} \mathrm{C}$ dengan rata-rata $28,4^{\circ} \mathrm{C}$. Sementara itu untuk seluruh perairan Bali SPL berkisar $26,4^{\circ} \mathrm{C}$ sampai $31,4^{\circ} \mathrm{C}$ dengan rata-rata $28,9^{\circ} \mathrm{C}$. Hasil tersebut hampir sama dengan penelitian Gaol (2014) di perairan Indonesia dan Yadnya (2015) di perairan Bali.

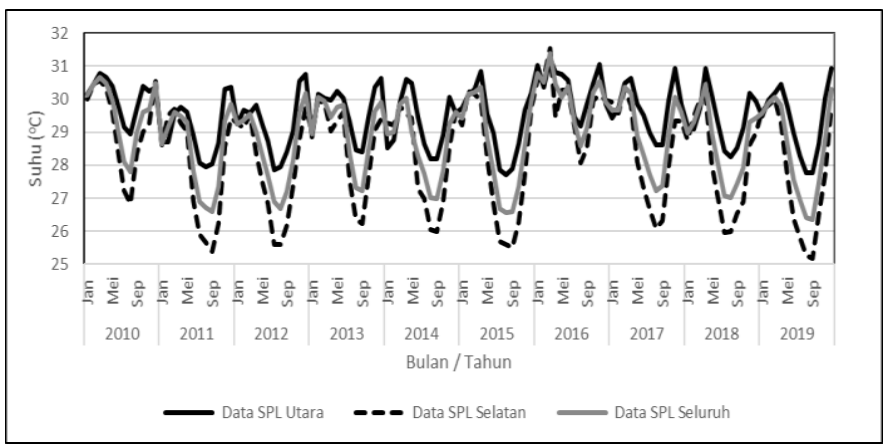

Gambar 2. Variabilitas Rata-rata SPL 2010-2019

Pada Gambar 2, SPL cenderung meningkat pada bulan November hingga bulan April dan melemah pada bulan selanjutnya. Secara garis besar, pada bulan November sampai April termasuk ke dalam musim barat dengan aktivitas atmosfer dipengaruhi oleh angin muson barat (Budaya, 2013). Hal tersebut serupa dengan hasil penelitian Susilo (2015) di Selat Bali dan Habibie (2014) di perairan Indonesia. Sementara itu, SPL mulai mengalami penurunan pada musim timur yang dipengaruhi oleh aktifitas angin muson timur (Budaya, 2013). Karakteristik SPL Bali Utara memiliki rata-rata maksimum dan minimum yang lebih hangat jika dibandingkan dengan SPL Selatan Bali. SPL Bali Selatan memiliki nilai minimum terendah jika dibandingkan dengan nilai minimum yang dimiliki SPL Utara Bali, yang juga didapatkan oleh penelitian Yadnya (2015). Menurut Hafizhurrahman et al. (2015), SPL selatan Bali memiliki nilai yang lebih dingin saat mencapai nilai terendah tiap tahunnya karena pada musim timur wilayah perairan selatan Bali terjadi fenomena upwelling yang menyebabkan masa air yang ada dilapisan bawah naik ke permukaan sehingga mempengaruhi SPL.

Pada Gambar 3 ditampilkan variabilitas curah hujan di perairan Bali selama 10 tahun dari 2010 hingga 2019. Berdasarkan hasil yang diperoleh, kisaran curah hujan di perairan Bali Utara adalah $0 \mathrm{~mm}$ sampai $495,04 \mathrm{~mm}$ dengan rata-rata 141,9 mm, sedangkan curah hujan diperairan Bali Selatan berkisar antara $10,27 \mathrm{~mm}$ sampai $556,92 \mathrm{~mm}$ dengan rata-rata $153,9 \mathrm{~mm}$. Sementara itu, untuk curah hujan di seluruh perairan Bali memiliki nilai antara $0 \mathrm{~mm}$ sampai $521,6 \mathrm{~mm}$ dengan ratarata $152,36 \mathrm{~mm}$.

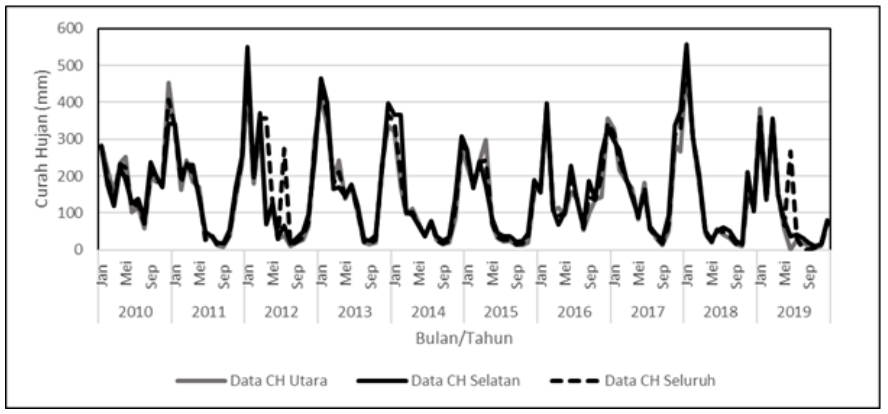

Gambar 3. Variabilitas Curah Hujan (CH) 2010-2019

Curah hujan di perairan Bali memiliki variabilitas dengan 1 puncak nilai maksimum dan 1 nilai minimum. Hal tersebut serupa dengan variabilitas curah hujan di pulau Bali (Yadnya, 2015). Melihat pada Gambar 3, curah hujan mulai mengalami peningkatan yang tajam mulai bulan November dan mencapai nilai tertinggi pada bulan Desember. Untuk bulan Januari sampai April, curah hujan mulai menurun namun masih dalam kategori tinggi. Menurut klasifikasi musim BMKG, $150 \mathrm{~mm}$ per bulannya merupakan batas curah hujan untuk penentuan musim hujan dan kemarau (Giarno et al., 2012). Pada bulan Mei sampai Oktober, curah hujan memiliki nilai yang rendah bahkan ada yang mencapai nilai $0 \mathrm{~mm}$. Secara umum kenaikan curah hujan terjadi dari bulan November sampai April dan menurun pada bulan Mei sampai Oktober. Hal tersebut sesuai dengan penelitian Avia (2013).

\subsection{Korelasi SPL dengan curah hujan di perairan Bali}

Berikut merupakan hasil korelasi antara SPL dengan curah hujan di perairan Bali yang disajikan pada Tabel 3. 
Tabel 3. Koefisien Korelasi SPL dengan Curah Hujan

\begin{tabular}{|c|c|c|c|c|c|c|c|c|c|}
\hline \multicolumn{9}{|c|}{ Nilai Koefisien Korelasi } \\
\hline & \multicolumn{3}{|c|}{ CH Utara } & \multicolumn{3}{c|}{ CH Selatan } & \multicolumn{3}{c|}{ CH Keseluruhan } \\
\hline & Lag 0 & Lag 1 & Lag 2 & Lag O & Lag 1 & Lag 2 & Lag 0 & Lag 1 & Lag 2 \\
\hline SPL Utara & 0,43 & 0,54 & 0,38 & 0,36 & 0,47 & 0,35 & 0,37 & 0,51 & 0,38 \\
\hline SPL Selatan & 0,70 & 0,60 & 0,35 & 0,64 & 0,54 & 0,28 & 0,63 & 0,57 & 0,33 \\
\hline SPL Total & 0,64 & 0,61 & 0,37 & 0,58 & 0,53 & 0,32 & 0,57 & 0,57 & 0,36 \\
\hline
\end{tabular}

Nilai koefisien korelasi pada Tabel 3 berkisar antara 0,28 sampai 0,70. Tingkat hubungan SPL dengan curah hujan adalah lemah sampai kuat. SPL Bali Utara memiliki korelasi kuat dengan curah hujan perairan Bali Utara dan seluruh perairan Bali hanya pada lag 1. Hal tersebut berarti curah hujan di perairan Bali Utara dipengaruhi oleh SPL Bali Utara 1 bulan sebelumnya. Sedangkan SPL selatan dan SPL Bali tanpa pembagian area memiliki korelasi kuat dengan curah hujan perairan Bali Utara, perairan Bali Selatan, serta perairan Bali secara keseluruhan pada lag 0 dan lag 1. Hal tersebut berarti, curah hujan di perairan Bali dipengaruhi oleh SPL Bali Selatan dan SPL rata diseluruh Bali pada bulan yang sama dan dengan SPL 1 bulan sebelumnya.

SPL Bali Utara memiliki tingkat hubungan yang kuat pada lag 1 dengan curah hujan perairan Bali Utara serta perairan Bali keseluruhan dengan nilai koefisien korelasi berurut-turut 0,54 dan 0,51. Kemudian SPL Bali Selatan memiliki tingkat hubungan kuat dengan curah hujan perairan Bali Utara, perairan Bali Selatan, dan perairan Bali tanpa pembagian area pada lag 0 dan lag 1 dengan nilai koefisien korelasi sebesar 0,54 sampai 0,70. SPL seluruh Bali juga memiliki korelasi kuat pada lag 0 dan lag 1 dengan curah hujan di seluruh daerah penelitian. Nilai koefisien yang diperoleh berkisar antara 0,53 sampai 0,64. Kisaran nilai tersebut hampir sama dengan penelitian Estiningstyas et al. (2007) di perairan Indonesia.

Gambar 4 - 6 merupakan grafik variabilitas SPL Bali dengan curah hujan $(\mathrm{CH})$ perairan Bali dan Tabel 4 merupakan koefisien korelasi pada musim barat. Dilihat pada Gambar 4 - 6, saat SPL turun maka curah hujan akan mengalami peningkatan begitupula sebaliknya.

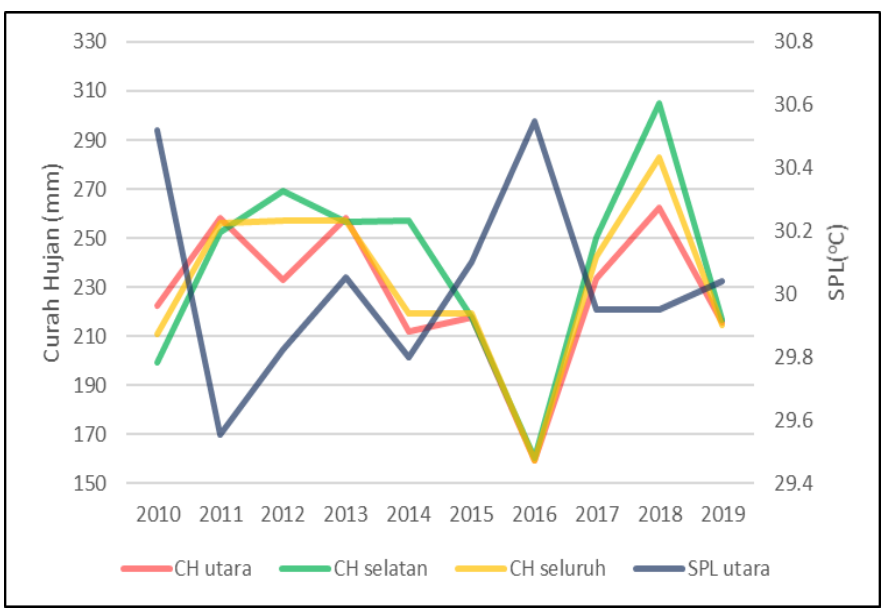

Gambar 4. Variabilitas SPL Bali Utara dengan $\mathrm{CH}$ di Perairan Bali

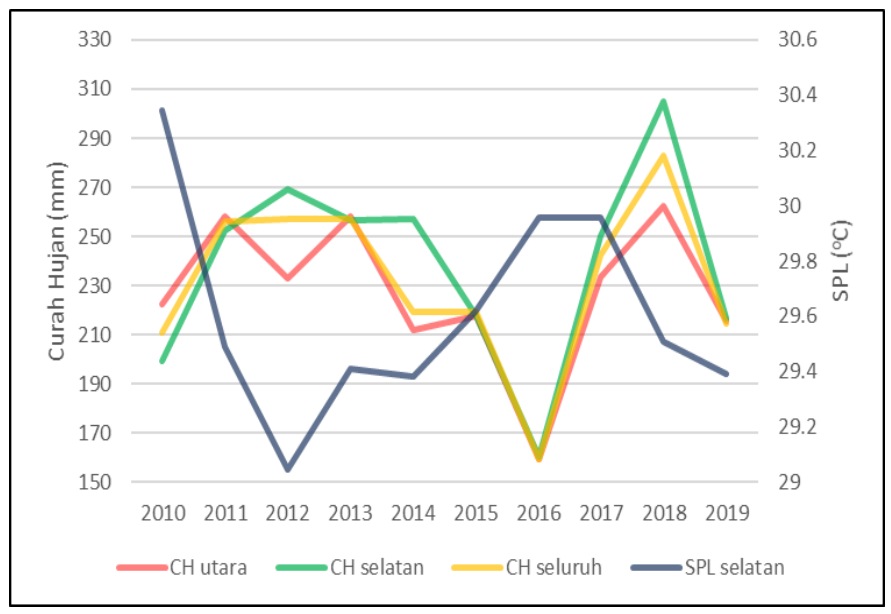

Gambar 5. Variabilitas SPL Bali selatan dengan $\mathrm{CH}$ di Perairan Bali

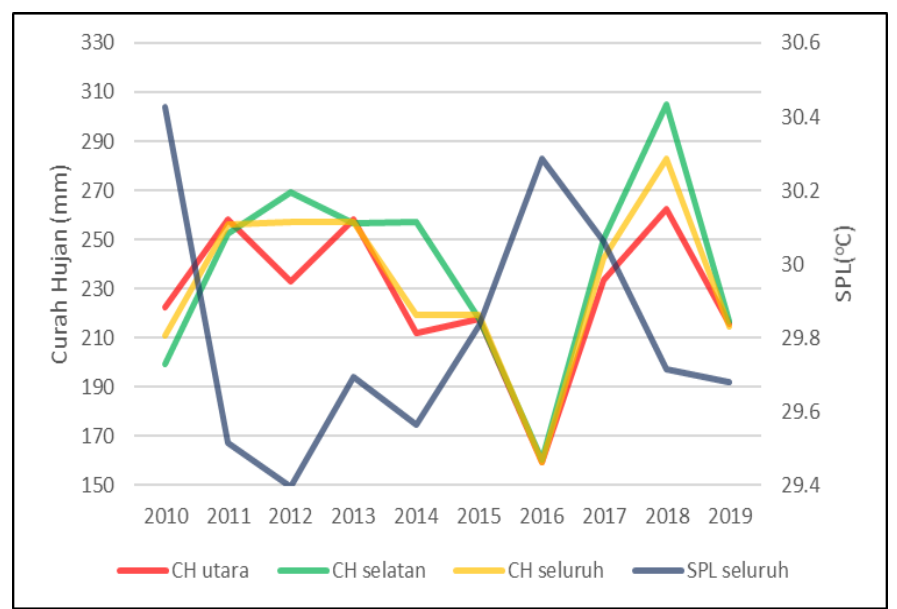

Gambar 6. Variabilitas SPL Bali dengan CH di Perairan Bali

Tabel 4. Koefisien Korelasi Musim Barat

\begin{tabular}{|c|c|c|c|}
\hline \multicolumn{4}{|c|}{ Nilai Koefisien Korelasi } \\
\hline & CH Utara & CH Selatan & CH Keseluruhan \\
\hline SPL Utara & $-0,63$ & $-0,74$ & $-0,69$ \\
\hline SPLSelatan & $-0,34$ & $-0,58$ & $-0,49$ \\
\hline SPL Total & $-0,50$ & $-0,69$ & $-0,61$ \\
\hline
\end{tabular}


Dari Tabel 4, diperoleh hasil bahwa pada musim barat korelasi antara SPL dengan curah hujan menunjukkan hubungan terbalik. Koefisien korelasi negatif menunjukkan bahwa peningkatan SPL menyebabkan penurunan curah hujan dan sebaliknya selama periode musim barat. Hal tersebut hampir sama dengan penelitian Estiningtyas (2007). Sementara itu, koefisien determinasi yang diperoleh pada musim ini adalah $\mathrm{R} 2=0,41$. Hal tersebut berarti pengaruh SPL terhadap curah hujan pada musim barat hanya sebesar $41 \%$ dan sebesar 58,5\% curah hujan dipengaruhi oleh faktor lain. Pada musim barat curah hujan tinggi namun tidak berkorelasi positif kuat dengan SPL. Kemungkinan selain SPL ada faktor yang mempengaruhi curah hujan pada musim ini. Faktor lain tersebut karena adanya Inter-tropical Convergence Zone (ITCZ) di wilayah Indonesia yang merupakan daerah pertemuan dari angin pembentuk awan penghasil hujan (Tukidi, 2010) dan Bali merupakan salah satu wilayah Indonesia yang memiliki curah hujan akibat distribusi ITCZ diatas $100 \mathrm{~mm}$ (Irjayanti et al., 2014)

Pada Gambar 7 -9 ditampilkan grafik variabilitas SPL dengan curah hujan $(\mathrm{CH})$ pada musim timur. Saat SPL mengalami penurunan, curah hujan juga mengalami penurunan dan sebaliknya saat SPL mengalami peningkatan, curah hujan mengalami peningkatan.

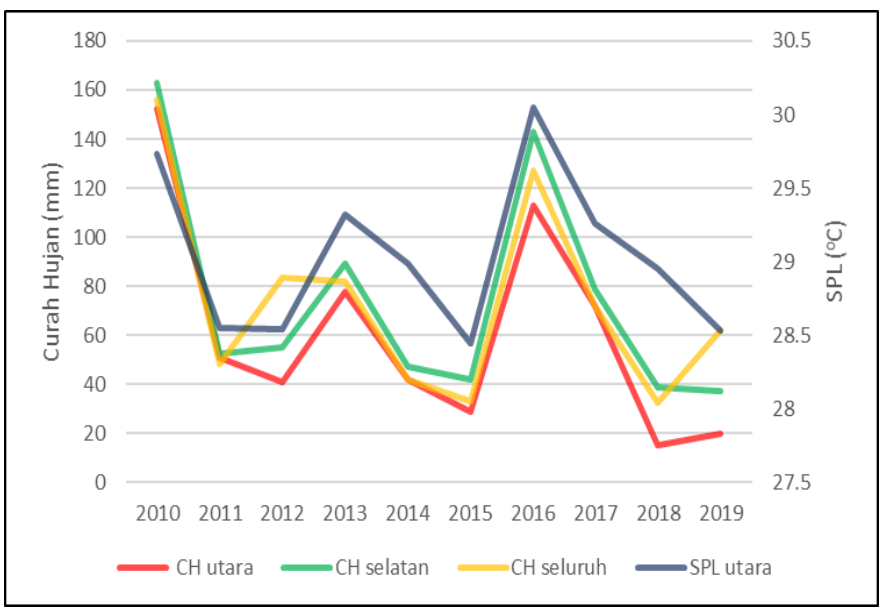

Gambar 7. Variabilitas SPL Bali Utara dengan $\mathrm{CH}$ di Perairan Bali

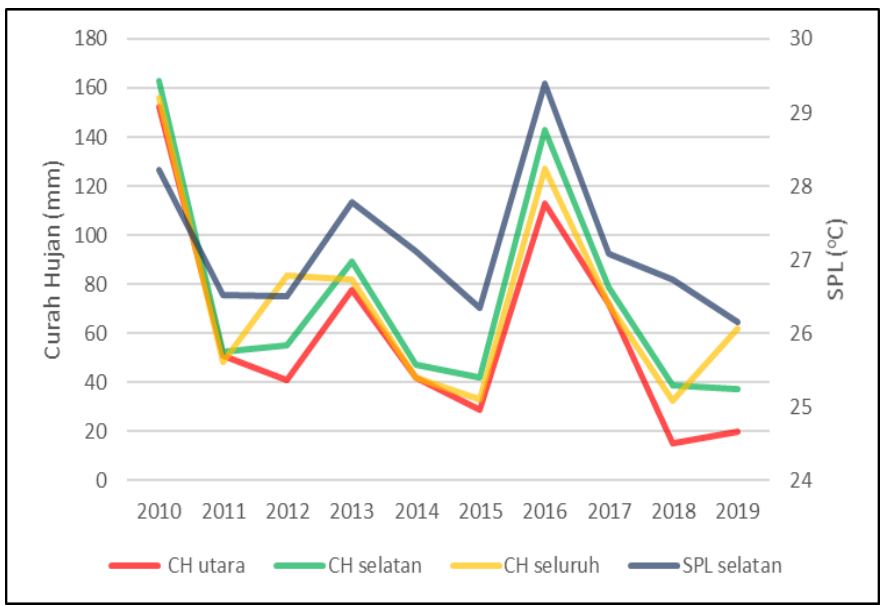

Gambar 8. Variabilitas SPL Bali Selatan dengan $\mathrm{CH}$ di Perairan Bali

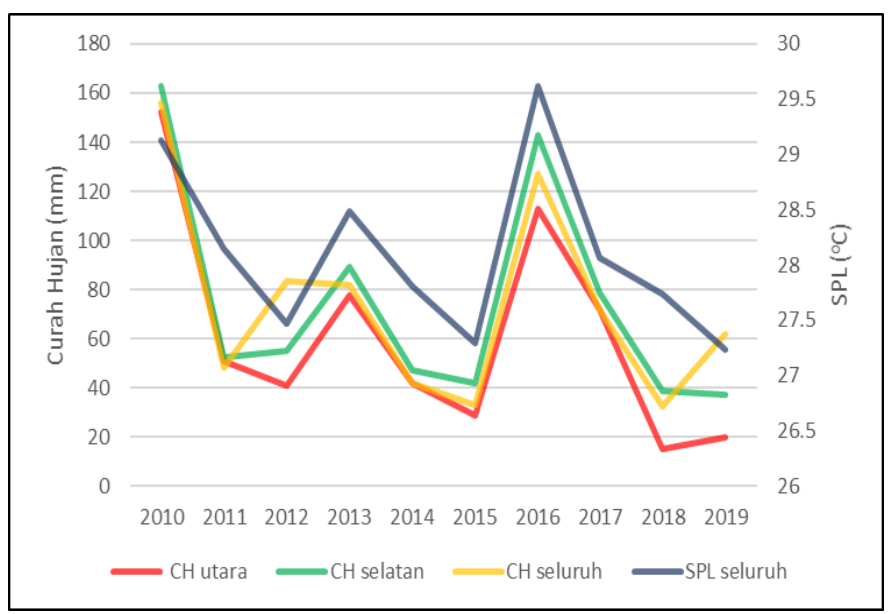

Gambar 9. Variabilitas SPL Bali dengan $\mathrm{CH}$ di Perairan Bali

Tabel 5. Koefisien Korelasi Musim Timur

\begin{tabular}{|c|c|c|c|}
\hline \multicolumn{4}{|c|}{ Nilai Koefisien Korelasi } \\
\hline & CH Utara & CH Selatan & CH Keseluruhan \\
\hline SPL Utara & 0,84 & 0,89 & 0,77 \\
\hline SPLSelatan & 0,83 & 0,88 & 0,77 \\
\hline SPL Total & 0,92 & 0,92 & 0,79 \\
\hline
\end{tabular}

Pada Tabel 5 disajikan nilai koefisien korelasi pada musim timur. Berbeda dengan musim barat, koefisien korelasi pada musim timur menunjukkan nilai positif dengan kisaran nilai 0,77 sampai 0,92. Itu menandakan bahwa SPL pada musim ini berpengaruh kuat terhadap curah hujan. Hal tersebut hampir sama dengan hasil penelitian Estiningtyas (2007). Sementara itu, nilai koefisien determinasi pada musim timur adalah $\mathrm{R} 2=0,76$. Hal tersebut berarti sebesar $76 \%$ SPL mempengaruhi curah hujan dan sebesar $24 \%$ curah hujan dipengaruhi oleh faktor lain.

Variabilitas curah hujan dipengarui oleh arah angin (Prasetya, 2011). Berikut merupakan peta arah angin pada musim barat dan musim timur dapat dilihat pada Gambar 10 dan Gambar 11. Data angin digunakan untuk mengetahui kecenderungan arah angin membawa uap air pada setiap musim 


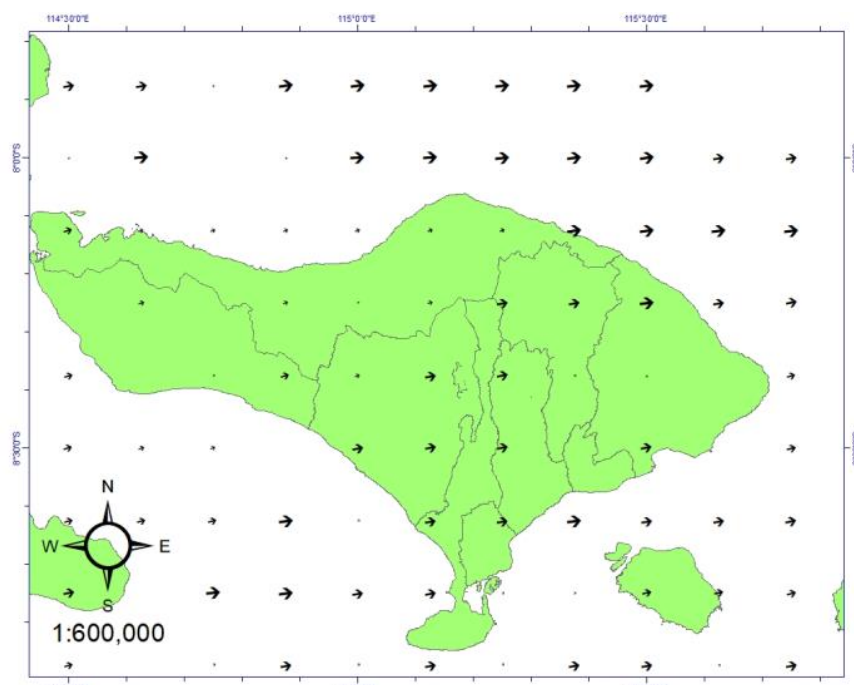

Gambar 10. Peta Rata-rata Angin Musim Barat

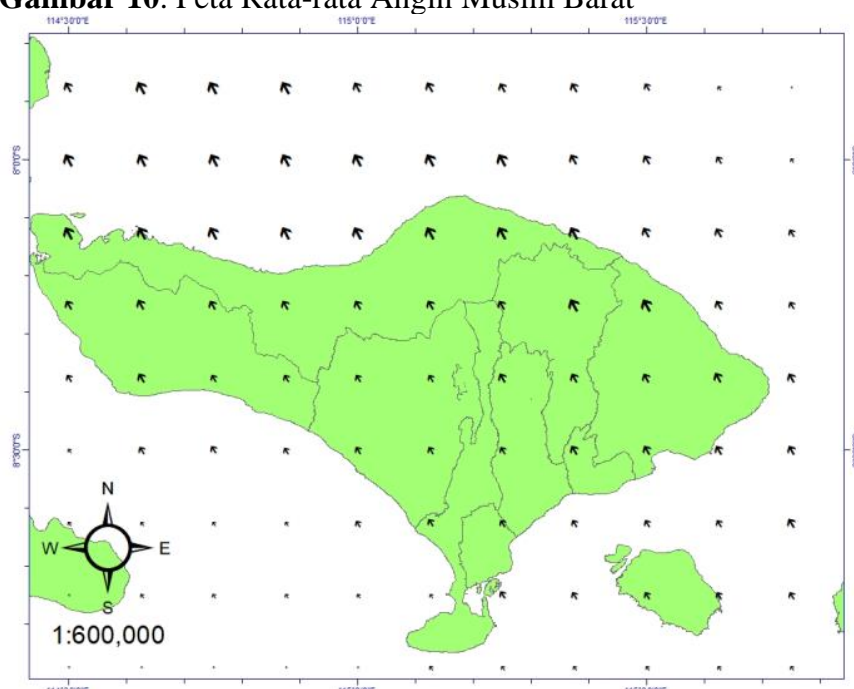

Gambar 11. Peta Rata-rata Angin Musim Timur

Berdasarkan Gambar 10, pada musim barat angin cenderung mengarah ke arah timur. Menurut Sudarto (2011) pada bulanbulan musim ini posisi matahari di bagian selatan sehingga tekanan lebih rendah berada di Australia dan arus angin berhembus dari benua Asia ke benua Australia. Jadi arah angin pada musim barat berpotensi membawa uap air ke arah timur. Kemudian untuk musim timur, angin cenderung mengarah ke barat laut. Menurut Mahagnyana et al. (2017) angin muson yang berhembus dari Australia ke Asia mempengaruhi pergerakan angin pada musim timur. Jadi arah angin pada musim ini akan berpotensi membawa uap air ke arah barat laut dan masih terdistribusi di wilayah kajian.

\section{Simpulan}

Berdasarkan hasil penelitian ini, kesimpulan yang diperoleh adalah variabilitas SPL Bali pada 10 tahun terakhir adalah nilai SPL bulanan mengalami peningkatan pada musim barat jika dibandingkan dengan SPL pada musim timur. Variabilitas curah hujan di perairan Bali selama 10 tahun terakhir mengikuti pola musim dengan nilai tertinggi terjadi pada musim barat dan menurun pada musim timur. Korelasi SPL tehadap curah hujan diperairan Bali memiliki tingkat hubungan yang lemah sampai kuat. Rata-rata SPL mempengaruhi curah hujan dengan kuat pada lag 0 dan lag 1. Pada musim barat, korelasi antara SPL dengan curah hujan di perairan Bali memiliki korelasi negatif dengan
JMRT, Volume 4 No 2 Tahun 2021, Halaman: 1-7 kisaran nilai koefisien korelasi -0,34 sampai -0,74. Sedangkan pada musim timur memiliki korelasi positif yang kuat dengan koefisien korelasi 0,77 sampai 0,92 .

\section{Ucapan terimakasih}

Penulis berterima kasih kepada Program Studi Ilmu Kelautan Fakultas Kelautan dan Perikanan Universitas Udayana yang telah menyediakan fasilitas penunjang dalam proses pengolahan data, Ocean Color dan Giovanni yang dikelola oleh National Aeronautics and Space Administration (NASA) yang telah menyediakan data SPL dan curah hujan, dan ECMWF yang telah menyedikan data angin, serta Beasiswa BIDIKMISI yang telah mendanai kuliah penulis selama 8 semester.

\section{Daftar Pustaka}

Adnyana IWS, As-Syakur AR. 2012. Aplikasi SIG Berbasis Data Raster untuk Pengkelasan Kemampuan Lahan di Provinsi Bali dengan Metode Nilai Piksel Pembeda. Jurnal Manusia dan Lingkungan, Vol.19 No.1: 21-29.

Avia LQ, editor. 2013. Analisis Pengaruh Dinamika Atmosfer dan Laut Terhadap Anomali Hujan Wilayah Indonesia Periode Januari Sampai Juni 2013. Bandung: Adira

Budaya BJ, Lestari P, Sofyan A. 2013. Perbedaan Pergerakan Angin Pada Musim Hujan dan Musim Kemarau dan Pengaruhnya Terhadap Dispersi Pencemar Udara di Kota Surabaya. Jurnal Teknik Lingkungan Vol 19 No 2: 140-149

Christian HJ. 2003. Global Frequency and distribution of lighting as observered from space by the optical transient Detector. 1084005 doi:10.1029/2002JD002347.

Estiningtyas W, Ramadhani F, Aldrian E. 2007. Analisis Korelasi Curah Hujan Dan Suhu Permukaan Laut Wilayah Indonesia, Serta Implikasinya Untuk Prakiraan Curah Hujan (Studi Kasus Kabupaten Cilacap). J.Agromet Indonesia. Vol.21 No.2

Fadholi A. 2013. Persamaan regresi prediksi curah hujan bulanan menggunakan data suhu dan kelembapan udara di Ternate. STATISTIKA: Journal of Theoretical Statistics and Its Applications. Vol.13 No.1

Gaol JL, Arhatin RE. Ling MM. 2014. Pemetaan Suhu Permukaan Laut Dari Satelit di Perairan Indonesia Untuk Mendukung "One Map Policy". Seminar Nasional Penginderaan Jauh 2014.

Giarno, Dupe ZL, Mustofa MA. 2012. Kajian Awal Musim Hujan dan Awal Musim Kemarau di Indonesia. Jurnal Meteorologi dan Geofisika. Vol 13 (1) : 1-8

Habibie MN, Nurani TA. 2014. Karakteristik dan Tren Perubahan Suhu Permukaan Laut di Indonesia Periode 1982-2009. Jurnal Meteorologi dan Geofisika. Vol.15 No. 1

Hafizhurrahman I, Kunarso, Suryoputro AAD. 2015. Pengaruh IOD (Indian Ocean Dipole) Terhadap Variabilitas Nilai Serta Distribusi Suhu Permukaan Laut dan Klorofil-A Pada Periode Upwelling di Perairan Sekitar Bukit Badung Bali. Jurnal Oseanografi. Vol 4 No 2: 423-433

Hermawan E. 2010. Pengelompokkan Pola Curah Hujan Yang Terjadi di Beberapa Kawasan P. Sumatera Berbasis Hasil Analisis Teknik Spektra. Jurnal Meteorologi Dan Geofisika. Vol. 11 No. 2: 75-85

Irjayanti p, Sulistya W, Setiawan SA. 2014. Penjalaran ITCZ di Wilayah Indonesia Berdasarkan Data Satelit TRMM. Jurnal Meteorologi dan Geofisika. Vol 11

Kartasapoetra, A.G., 2004. Klimatologi Pengaruh Iklim terhadap Tanah dan Tanaman. PT Bumi Aksara, Jakarta.

Kendall MG, Struat A. 1947. The Advanced Theory of Statistic. Second Edition Hafer Publishing Company. Newyork

Lestari RE, Putri AR, Nugraheni IR. 2017. Analisis Korelasi Suhu Muka Laut dan Curah Hujan di Stasiun Meteorologi Maritim Kelas II Kendari Tahun 2005 - 2014. Prosiding SNFA (Seminar Nasional Fisika dan Aplikasinya) 2017. E-ISSN: 2548-8325 / P-ISSN 2548-8317

Mahagnyana, M., Limaran, G. D., \& Fadlan, A. (2017). Pengaruh Monsun Terhadap Kesuburan Perairan Utara Jawa dengan Menggunakan Satelit Aqua Modis. Unnes Physics Journal. Vol.6 No.1: 37-40.

Miftahuddin. 2016. Analisis Unsur-unsur Cuaca dan Iklim Melalui Uji MannKendall Multivariat. Jurnal Matematika, Statistika, \& Komputasi. Vol. 13, No. 1, 26-38

Nugroho YN, Ferdya, Wandayantolis. 2014. Verifikasi Data Estimasi Curah Hujan dari Satelit TRMM dan Pos Pengamatan Hujan BMKG di Sulawesi Utara. Jurnal MIPA UNSRAT online. 3 (1) 35-39 
Nuryanto DE, Badriyah IU. 2014. Pengaruh Perubahan Suhu Permukaan Laut Terhadap Curah Hujan Benua Maritim Indonesia Pada September 2006. Jurnal Meteorologi dan Geofisika, VoL. 15 No 3: 147-155

Pertiwi MA, Kahar S, Sasmito B, Marpaung S. 2015. Analisis Korelasi Suhu Permukaan Laut Terhadap Curah Hujan Dengan Metode Penginderaan Jauh Tahun 2012-2013 (Studi Kasus : Kota Semarang). Jurnal Geodesi Undip Volume 4, Nomor 1,

Prasetya, R. 2011. Analisis Curah Hujan Akibat Siklon Tropis Nangka, Parma dan Nida di Sulawesi Utara. Skripsi. Manado: Universitas Sam Ratulangi.

Prasetia R, As-syakur AR. Validation of TRMM Precipitation Radar Satellite Data Over Indonesia Region. Theor Appl Climatol 112: 575-587

Qudratullah MI, Asrizal, Kmus Z. 2017. Analisis Unsur - Unsur Cuaca Berdasarkan Hasil Pengukuran Automated Weather System (Aws) Tipe Vaisala Maws 201. Pillar of Physics, Vol. 9: 17-24

Rindrasih E, Mujiasih S. 2015. Respon Industri PariwisataTerhadap Potensi Cuaca Ekstrim Darat dan Laut di Pulau Bali. Makalah PIT Riset Kebecandaan ke-2 2015

Sharifi E, Steinacker R, Saghafian B. 2016. Assessment of GPM-IMERG and Other Precipitation Products against Gauge Data under Different Topographic and Climatic Conditions in Iran: Preliminary Results. Remote Sensing, Vol.8 No.2: 135. doi: 10.3390/rs8020135

Sudarto. 2011. Pemanfaatan Dan Pengembangan Energi Angin Untuk Proses Produksi Garam Di Kawasan Timur Indonesia. Jurnal TRITON. Vol 7 No 2: $61-7$

Suharyanto, Rinaldy J, Arya NN. 2016. Analisis Risiko Produksi Usaha Tani Padi Sawah di Provinsi Bali. Journal of Agribusiness and Runal Development. Vol 1:70-77

Sukreno B. 2010. ENSO Impact on SST and SLA Variability in Indonesia. Jurnal Kelautan Nasional. Vol 5 No 1

Susilo E. 2015. Variabilitas Faktor Lingkungan Pada Habitat Ikan Lemuru di Selat Bali Menggunakan Data Satelit Oseanografi dan Pengukuran Insitu. Omni-Akuatika Vol. XIV No. 20: 13-22

Susilowati, Sadad I. 2015. Analisa Karakteristik Curah Hujan di Kota Bandar Lampung. Jurnal Konstruksia. Vol 7 No 1

Tresnawati R, Komalasari KE. 2011. Skenario Tenggang Waktu SST Nino 3.4 Terhadap Curah Hujan Untuk Meningkatkan Akurasi Prediksi Kalman Filter. Jurnal Meteorologi dan Geofisika Vol 12 No3: 243251

Triatmojo B. 1998. Studi Kesimbangan air pulau Jawa. Forum Teknik No. 1

Tukidi. 2010. Karakter Curah Hujan di Indonesia. Jurusan Geografi FIS UNNES. Vol 7 No 2.

Wahdianty R, Ridwan I, Nurlina. 2016. Verifikasi Data Curah Hujan dari Satelit TRMM denganPengamatanCurahHujan BMKG Di ProvinsiKalimantan Selatan. Jurnal Fisika FLUX. Volume 13 (2).

Widiyana S R. 2013. Prediksi Curah Hujan Bulanan Dengan Prediktor Suhu Muka Laut Di Stasiun Meteorologi Merauke. Sekolah Tinggi Meteorologi Klimatologi dan Geofisika

Wijaya A. 2015. Variabilitas Suhu Permukaan Laut Perairan Indonesia Dar Data TRMM Microwave Imager. Prosiding Seminar Nasional Geografi UMS. ISSN: 2460-0474

Wirjohamidjojo DS, Sugarin. 2008. Praktek meteorologi Kelautan. Jakarta: Badan Meteorologi dan Geofisika

Wiyadi SH. 2012. Variabilitas Kesuburan Perairan dan Hubungannya Dengan Kondisi Oseanografi di Selat Lombok. Sekolah Pascasarjana Institut Pertanian Bogor. 90 hal.

Wulandari A, Muliadi, Apriyansyah. 2018. Pengaruh Sebaran Uap Air terhadap Curah Hujan di Kalimantan Barat. Prisma Fisika. Vol. 6 No. 3: 160 - 166
Yadnya IMS, Baskoro WT, Putra MDJ. 2015. Analisa Time Lag Suhu Permukaan Laut Yang Berhubungan Dengan Curah Hujan RataRata Dasarian Di Provinsi Bali. Buletin Fisika. Vol. 16 (2) 